\title{
Religion, kirke og velfærdsstat - er der en sammenhæng?
}

\author{
Om velfærdsstatens opståen og udvikling \\ JØRN HENRIK PETERSEN \& KLAUS PETERSEN ${ }^{1}$
}

\begin{abstract}
ENGLISH ABSTRACT: The article presents a survey of previous research approaches analysing the origin and development of welfare states and their different institutional structures with focus on their respective use of religion as an explanatory variable. This paves the way for a presentation of recent endeavours to attribute religion a greater role in understanding the development of different welfare state regimes. The article is closed by a critical discussion of the new approach: Does a Lutheran social doctrine exist at all? What is the criterion of falsification? How is the concept "welfare state" understood? What does a "projection back in time" mean? How are "religious social doctrines" actually channelled into policies concerned with the institutional structure?
\end{abstract}

DANSK RESUME: Artiklen præsenterer en oversigt over de hidtidige forskningstilgange i forståelsen af velfxrdsstaters forskelligartede opståen og udvikling, herunder religionens rolle i forklaringsmodellerne. Det følges af en præsentation af nyere tilgange, der i højere grad tillægger religionen og de religiøst betingede "sociale doktriner" en selvstændig betydning som forklarende variabel. Den sluttes med en række kritiske spørgsmål til denne nye forskningstilgang.

KEYWORDS: welfare state; religion; religious social doctrines; theories of modernisation; power resource theory; labour mobilization approach; state capacity, regime theory.

1 Center for Velfærdsstatsforskning, Institut for Statskundskab, Syddansk Universitet, Campusvej 55, 5230 Odense M.jhp@sam.sdu.dk; klaus.petersen@hist.sdu.dk. Artiklen er et resultat af projektet Dansk Velfærdshistorie, som er finansieret af Carlsbergfondet. 


\section{Religionens tilbagekomst i samfundsdebat og velfærdsforskning}

Religion i almindelighed og kristendom i særdeleshed er kommet på samfundsforskningens og mediernes dagsorden. For 10-15 år siden betragtede samfundsdebattører og samfundsforskere argumenter, der henviste til det religiøse, og analyser, som knyttede en sammenhæn til religionen, med skepsis. De blev i bedste fald set som 'eksotiske' bidrag. I dag flyder avisernes debatsider over med henvisninger til religion, kristendom, islam osv., og religion optræder i overskrifter på samfundsvidenskabelige artikler og i titler på monografier. Det kan der være mange forklaringer på, herunder ikke mindst en genopdukket åndelighed i samfundet og de kulturmøder, som er fulgt i immigrationens og globaliseringens kølvand.

Man kan med Vagn Andersen (2009) stille spørgsmålet, om det, der opfattes og præsenteres som 'religion', i kritisk-filosofisk forstand er religion forstået som "intellectual honourable religion" i modsætning til "pseudo-religious ideology" (Andersen 2009, 46 note 2), og man kan diskutere, om religion i empirisk forstand reelt har fået større betydning; men det er givet, at religion (kristendom) og kirke i dag indgår med større tyngde i diskussionen om den danske samfundsmodel - den danske velfærdsstat. I en ledende artikel i BT skrev Erik Meier Carlsen (2006), at "den stærke danske velfærdsstat i sig selv er ... udtryk for, at kristendommen er trængt ind i alle samfundets, hverdagslivets og det sociale livs forgreninger. Vi er kristne uden at sige, at vi er kristne - og næsten uden at gå i kirke".

Denne påstand om en skjult og implicit kristen dimension bag den danske velfærdsmodel genfindes både i den offentlige debat og i forskningen. Vel kan der være noget om pointen, men det er nu en gang svært at finde empirisk belæg for det fornemmede, det implicit underforståede, som jo netop ikke træeder tydeligt frem.

I velfærdsstatsforskningen er der en markant øget interesse for den mulige sammenhæng mellem den religiøst-konfessionelle prægning af de enkelte nationer og udformningen af 'deres' velfærdsstat. Det er en sammenhæng, som er præget af dobbelthed. På den ene side ses velfærdsstaten som led i en sekulariseringsproces, fordi religionen i en befolkning, som i kraft af de velfærdsstatslige institutioner er mindre sårbar, spiller en aftagende rolle i hverdagslivet (Norris \& Inglehart 2004; Manow 2008). På den anden side er religiøse (konfessionelle) eller religiøst farvede normer virksomme i samfundskulturen (Kahl 2005). I Kahls lys træder velfærdsstaten ikke frem som sekulariseringens instrument, men som et sekulariseret udtryk for forskelligartede 'konfessionelle' sociale doktriner. De religiøse værdier får derved langsigtede social- og velfærdspolitiske virkninger, fordi de er indkapslet i de enkelte landes kultur.

Vi vil med denne artikel dels give en oversigt over den hidtidige forskning vedrørende velfærdsstaternes opståen og udvikling, herunder religionens rolle i 'forklaringsmodellerne', dels præsentere den nyere forskning om kristendommens/lutheranismens betydning og dels rejse en række kritiske spørgsmål: Kan man overhovedet tale om en (konfessionel) 'luthersk sociallære' svarende til den katolske? Kan der formuleres et 
falsifikationskriterium i forhold til disse 'forklaringsmodeller"? Hvad forstår man i denne forskning ved 'velfærdsstaten'? Kan et efterkrigstidsfænomen projiceres bagud i tid, som forskningen gør? Hvordan kanaliseres religiøse 'sociale doktriner' til mål af betydning for velfærdsstaternes institutionelle udformning?

\section{Den generelle baggrund}

Den præ-politiske brug af termen 'velfærdsstat' kan føres tilbage til omkring 1840-50, men begrebet vandt først politisk fodfæste og indgik i dagligsproget fra omkring 194950 (Petersen \& Petersen, under udgivelse a). I politisk forstand er det derfor en term, der daterer 'velfærdsstaten' som et efterkrigstidsfænomen. På den anden side udelukker det ikke, at man søger velfærdsstatens rødder længere tilbage i tid, og at man tidsfæster velfærdsstatens 'oprindelse' betydeligt tidligere. Den omfattende forskning med velfærdsstaten som genstand berører derfor både dens opståen og dens udvikling, selv om det ikke er alle forskningsmæssige bidrag, der klargør, om de har fokus på den ene, den anden eller begge.

Om end man - også med mening - kan bevæge sig endnu længere tilbage i tiden, vil de fleste forskere være enige om, at velfærdsstaten er barn af en række grundlæggende samfundsmæssige ændringer, der både førte til og udsprang af processer, som ændrede et landbrugsdomineret, lokalpræget og traditionsbåret samfund over et industrialiseret, nationalt og moderne samfund til et overvejende serviceproducerende, internationalt og måske post-moderne samfund. Dramatisk kan man som baggrundsfaktorer tale om industrielle, politiske og nationale revolutioner.

Industrialiseringen betød nedgang i landbrugets beskæftigelse, fald i landbrugsbefolkningens befolkningsandel, urbanisering, udvikling af en urbaniseret livsform, fremvækst af en urban arbejderklasse med beskæftigelse i industriel virksomhed, nødvendigheden af en veluddannet, læse- og skrivekyndig arbejdsstyrke, anerkendelse af arbejdsløshed som vilkår, der kan gøre det umuligt at finde beskæftigelse, selv om viljen er til stede, udvikling af en funktionærgruppe som led i dannelse af en middelklasse og typisk - om end afbrudt af cykliske svingninger - en betydelig økonomisk vækst.

Ændringerne blev ofte ledsaget af betydelig befolkningsvækst, ændringer i befolkningens sammensætning, en mere markant opdeling i den arbejdende og den ikkearbejdende del af befolkningen, faldende børnedødelighed, langtidsvækst i forventet restlevetid, ændrede familiemønstre, og en begyndende udvikling af sociale ordninger, der - mere eller mindre - sikrede levefoden ved tilbagetrækning fra arbejdsmarkedet, sygdom, ulykke, arbejdsløshed, invaliditet m.v.

Ændringsprocesserne gik i mange lande med en ikke særligt udviklet 'statslig kapacitet' hånd i hånd med statsdannelse og 'nation building', der betød centralisering af 'magten til at styre', udvikling af et professionaliseret administrativt apparat, udvikling af statslig kapacitet til overvågning og kommunikation. 
Om end der kan være tale om tidsmæssige forskydninger, præges de afgørende ændringsprocesser også af massemobilisering, øget demokratisering, udvikling af politiske partier, udvidet stemmeret, større vægtlægning på individets borgerlige status, den fremvoksende arbejderklasses politiske mobilisering og øget opmærksomhed på 'det sociale spørgsmål' eller 'arbejderspørgsmålet', som det - lidt forskelligt i forskellige lande - blev kaldt.

Disse mange ændringer er blevet tillagt forskellig vægt i forsøgene på at forstå, hvad der betingede velfærdsstaternes opståen, deres udvikling og - på et senere trin i forskningen - deres forskelligartede indretning.

No theory has yet won recognition as the sole legitimate solution, because proponents of theories that lose a test often claim that their ideas were unjustly undermined by unfair operationalizations or inappropriate analyses (Amenta 1993, 752).

Amentas konstatering er stadig gyldig. Formålet med denne artikel er alene at præsentere på de forskellige 'forklaringsformer', mens vi ikke går ind i de enkelte undersøgelsers tekniske udformning, operationaliseringer, datagrundlag og empiriske resultater. Alber (1979), Skocpol \& Amenta (1986), Amenta (1993) og Pierson (2006) giver glimrende og detaljerede oversigter over den omfattende forskning.

\section{Forklaringsmodeller}

\section{Moderniseringsteorier}

Forskningen kan rubriceres på mange måder. I det følgende har vi valgt et overordnet sigte, så vi indskrænker os til at se på kernen i moderniseringsteorierne, magt-ressource- og arbejdermobiliseringstilgangen, regimeteorierne, og teorier med vægt på udvikling af 'statslig kapacitet', idet vi ser på deres forhold til religion i almindelighed og protestantisme i særdeleshed. Herved lægges op til behandling af nyere teori, der i højere grad inddrager religion og kultur som forklarende variable.

Moderniseringsteorien har sit udspring hos Stein Rokkan (1973; 1983). Den har fundet anvendelse som forklaring på velfærdsstaternes udvikling i et stort projekt under ledelse af Peter Flora (1981; 1983). De enkelte samfunds 'modernisering' ses som en relativ ensartet og universel proces. Religion spiller primært en rolle som en faktor, der kan fremskynde eller forsinke udviklingen. Rokkan (Flora 1983, 21-22) konstaterede bl.a., at den protestantiske dominans i Norden havde fremmet en mobilisering 'fra neden' i kraft af tidlig udvikling af læse- og skrivekyndighed samt mobilisering af de lavere strata i massepolitikken. Kirkens forhold til statsapparatet mindskede risikoen for konflikt. Den katolske kirkes 'over-territoriale' indflydelse betød derimod en mobilisering 'fra oven', mens den (i katolske lande) sene udvikling af læse- og skrivekyndighed forsinkede en spontan massemobilisering. Konflikter over 
kontrollen med uddannelsessystemet førte til, at den katolske kirke mobiliserede mod staten i velkendte konflikter mellem stat og kirke.

Protestantismen blev set som en katalysator i sekulariseringsprocessen. ${ }^{2}$ Sammen fremmede de ændringen fra et traditionelt samfund til et moderne massedemokrati med den nationale velfærdsstat som kerne.

Den protestantisme, Rokkan og Flora havde for øje, var den, der havde fundet udtryk i de skandinaviske, lutherske statskirker - mens de ikke på samme måde rettede opmærksomheden mod den reformerte protestantismes betydning for en 'forsinket' og mere 'indskrænket' velfærdsstatsudvikling (Manow 2008, 14). Manow (2008, 7-8) ser modstillingen af katolicisme og protestantisme som mere vildledende end oplysende, fordi den ignorerer forskellene mellem de lutherske statskirker i Skandinavien og den reformerte protestantisme i Schweiz, Holland, Storbritannien og USA. De to former for protestantisme har, understreger han, forskellig 'socialdoktrin', og deres normative vægtlægning på stat, lokalsamfund, kirke, familie og individ adskiller sig mere, end den lutherske og katolske 'sociallære' gør indbyrdes.

Moderniseringsteoriens velfærdsstatslige 'idealtype' er universel i et samfund, der er centralstatsligt organiseret, har statskirke, kulturel, religiøs og etnisk homogenitet, friktionsløs demokratiseringsproces og kun få veto-aktører (Manow 2008, 15). Referenceeksemplet er Skandinavien - den protestantiske velfærdsstat: “... what Peter Flora discovered as the differentia specifica of the 'Protestant welfare state', was later discovered by Walter Korpi and his followers (notable Gösta Esping-Andersen) as the 'Social Democratic welfare state'" (Manow \& van Kersbergen 2009, 15).

\section{Polanyis transformationsteori}

Om end hans transformationsteori ikke sigter på komparativ analyse, men på afdækning af forholdet mellem det 19. århundredes civilisation og dens kollaps i det 20. århundrede, er den 'åndelige fader' til magt-ressourceteorien Karl Polanyi (1957 [1944]). Den idé, som styrer hans fortælling, knytter sig til 'dobbeltbevægelsen'. Udgangspunktet er, at det 'selv-regulerende marked' forudsætter en 'varegørelse' ("commodification") af "labor, land and money", men de er ikke varer. "Labor" er betegnelse for "a human activity which goes with life itself" og "land" for "nature" (Polanyi 1957: 72). 'Varegørelsen' løsriver produktionens organisation fra samfundets sociale institutioner. Samfundet underordnes det økonomiske system. Denne bevægelse fremkalder imidlertid en 'samfundsmæssig, selvbeskyttende modbevægelse', der vil regulere markedet - en "de-commodification".

2 "At the risk of some simplification, it can be said that Protestantism divested itself as much as possible from the three most ancient and most powerful concomitants of the sacred - mystery, miracle, and magic. This process has been aptly caught in the phrase "disenchantment of the world"" (Berger 1967, 111). 
Dobbeltbevægelsen

can be personified as the action of two organizing principles in society, each of them setting itself specific institutional aims, having the support of definite social forces and using its own distinctive methods. The one was the principle of economic liberalism, aiming at the establishment of a self-regulating market, relying on the support of the trading classes, and using largely laissez-faire and free trade as its methods; the other was the principle of social protection aiming at the conservation of man and nature as well as productive organization, relying on the varying support of those most immediately affected by the deleterious action of the market - primarily, but not exclusively, the working and the landed classes - and using protective legislation, restrictive associations, and other instruments of intervention as its methods (Polanyi 1957, 132).

Da 'dobbeltbevægelsen' karakteriserede alle vestlige lande, var den ikke påvirket af religiøse forskelligheder landene imellem.

Thus under the most varied slogans with very different motivations a multitude of parties and social strata put into effect almost exactly the same measures in a series of countries in respect to a larger number of complicated subjects (Polanyi, 1957: 147-48).

Hos Polanyi er det således ikke en bestemt gruppe, der bærer udviklingen frem mod velfærdsstaten; men han specificerer ikke, hvilke grupper det i det enkelte land drejer sig om, selv om det kan være udslaggivende for den form, velfærdsstaten får.

\section{Arbejdermobiliseringstilgangen}

Anderledes i den nyere arbejdermobiliseringstilgang, der lader velfærdsstatens udvikling være en funktion af arbejderklassens styrke (Stephens 1979). Det giver ikke plads for religionen, som kun er relevant, hvis religiøse forskelle fremmer organisationsdannelser, der styrker eller - mere typisk - svækker de klassebaserede organisationer (Huber \& Stephens 2001a; 2001b; Korpi 2006). På den anden side erkendes det, at der - målt ved de sociale udgifter som andel af bruttonationalproduktet - under kristendemokratisk ledelse kan udvikles lige så generøse velfærdsstater som under socialdemokratisk ledelse (Wilensky, 1981; Schmidt, 1982; Kersbergen, 1995). I lys heraf fokuseres der så mere på velfærdsstaternes indretning, idet det hævdes, at socialdemokratiske velfærdsstater i højere grad har realiseret målet om "de-commod- 
ification"3 (Allan \& Scruggs 2004; Scruggs \& Allan 2006), ${ }^{4}$ eller det understreges, at hvor socialdemokratiske partier ikke har været afgørende aktør, har de indirekte - via partikonkurrencen - påvirket de kristendemokratiske partier til at følge en mere generøs, intervenerende og universel politik, end de ellers ville have gjort (Huber \& Stephens 2001; Korpi 2006) - hvordan man så ellers vil begrunde denne påstand.

Arbejdermobiliseringstilgangen argumenterer således, at en svækkelse af venstrekræfterne ved konfessionelle opdelinger af arbejderklassen hæmmer velfærdsstaternes udvikling, men accepterer omvendt, at socialdemokratisk pres på de kristendemokratiske partier alligevel kan betyde generøse velfærdsstater. Det betyder på den anden side, at de er mindre "de-commodifying" på grund af den katolske sociallære (subsidiaritetsprincippet). ${ }^{5}$ Hertil kommer andre forhold (Manow 2008, 21-22):

a) I den tidlige socialstatsudvikling var det ikke alle steder, at 'arbejderspørgsmålet' var i fokus. Det var snarere uddannelse og forsorg, der betød kompetencekonflikter mellem kirke og nationalstat;

b) Påstanden om identiske interesser og overensstemmende socialpolitiske programmer mellem den katolske kirke og de kristendemokratiske partier (Korpi 2006; Stephens 1979) er tvivlsom (Kalyvas 1996);

c) Protestantismen negligeres i almindelighed og forskellen på lande med protestantiske statskirker og lande præget af reformert protestantisme forbises. Det gør det let at identificere de socialdemokratiske partier i Skandinavien som dominerende bærere af velfærdsstatsudviklingen;

d) Man har fokuseret på opkomsten af den moderne kapitalisme i kølvandet på den industrielle revolution, mens der ikke har været tilsvarende fokus på betydningen af udviklingen af den moderne nationalstat (Flora, Kuhnle \& Urwin 1999).

3 "Stripping society of the institutional layers that guaranteed social reproduction outside the labor contract meant that people were commodified. In turn, the introduction of modern social rights implies a loosening of the pure commodity status. De-commodification occurs when a service is rendered as a matter of right, and when a person can maintain a livelihood without reliance on the market" (Esping-Andersen 1990, 21-22.

4 "Advocates of the class mobilization and partisan thesis, like Korpi and Palme or Esping-Andersen, point out that partisanship and class power should not necessarily explain aggregate spending but the degree of decommodification of risks in the welfare state" (Allan and Scruggs 2004, 503).

5 Subsidiaritetsprincippet er en del af den katolske sociallære, hvorefter en overordnet enhed i samfundet ikke må fratage en underordnet enhed ansvar eller kompetence, medmindre det i en given situation skønnes nødvendigt. Subsidiaritetsprincippet har rod i de principielle anvisninger for samfundsstrukturen, som pave Pius 11. gav i sin sociale encyklika Quadragesimo Anno (1931). Princippet indebærer, at et overordnet led i hierarkiet er subsidiært eller stedfortrædende i forhold til alle underliggende led. Således skal staten skabe de nødvendige forudsætninger for $\mathrm{fx}$ familien, fagforeningerne og det frivillige hjælpearbejde, men bør først træde aktivt til, hvis disse mindre fællesskaber af en eller anden grund ikke selv kan løse en konkret opgave. 
Det er denne forbindelse mellem nationalstats- og velfærdsstatsdannelsen, Manow (2008) fokuserer på. Skole, opdragelse, dannelse og social forsorg som centrale led i nationalstatens udvikling skabte konflikt med kirken som hidtidig ansvarlig for disse områder - og denne konflikt spejles i partisystemerne i lande, som oplevede en sådan stat/kirke-konflikt.

Omvendt førte et statsligt ansvar for disse områder ikke i Skandinavien til en konflikt mellem de lutherske statskirker og nationalstaten. Derfor har konfessionelle partier kun haft begrænset indflydelse. I stedet opstod som resultat af en konflikt mellem land og by agrar-partier, som ikke i samme grad kendes i de kontinentaleuropæiske lande.

\section{Statscentrerede tilgange}

Fra midten af 1980 'erne begyndte flere at anlægge 'statscentrerede' tilgange. Evans, Rueschemeyer \& Skocpol (1985) gav deres nu klassiske arbejde titlen "Bringing the State Back In". De to kernebegreber var staten og den 'statslige kapacitet'. Skocpol $(1985,29)$ ser staten som

... a set of administrative, policing, and military organizations headed, and more or less well coordinated by, an executive authority. Any state first and fundamentally extracts resources from society and deploys these to create and support coercive and administrative organizations

og den 'statslige kapacitet' udspringer af statens autonomi:

States conceived as organizations claiming control over territories and people may formulate and pursue goals that are not simply reflective of the demands or interests of social groups, classes or society. This is what is usually meant by 'state autonomy'. Unless such independent goal formulation occurs, there is little need to talk about states as important actors.

Pointen er da, at der til enhver tid eksisterer samfundsmæssige 'behov', men deres 'tilfredsstillelsesgrad' afhænger af de statslige aktørers 'kapacitet', som bl.a. er bestemt af statens evne til at frembringe offentlige indtægter, principperne for den bureaukratiske organisation, et specialiseret administrativt system osv.

Er der i udgangssituationen en stærk administrativ kapacitet og interesse for at udvikle socialpolitik som middel til at fremme økonomisk udvikling og svække folkelig utilfredshed, vil der tidligt blive iværksat initiativer (Flora \& Alber 1981). Under alle omstændigheder vil bureaukratiets evne til at skabe og videreudvikle socialpolitiske initiativer gennem social læring være af betydning, (Heclo 1974; Weir \& Skocpol 1985). Graden af centralisering og bureaukratisering som led i "state building" spiller 
også en rolle (Castles 1982; Orloff \& Skocpol 1984; Hicks \& Misra 1993). Hertil kommer betydningen af "political legacies", dvs. betydningen af allerede institutionaliseret politik for den senere udvikling - "precedents that have shaped the later forms and expansion of welfare state programs" (Huber, Ragin, Stephens 1993, 713; Hicks \& Misra 1993, 677-678).

Esping-Andersen $(1990,29)$ taler om "the historical legacy of regime institutionalization" som en af tre udslaggivende faktorer bag hans regimeteori, jf. nedenfor. Kirkens forhold til staten i fortiden kan være af stor betydning for den 'statslige kapacitet', som bl.a. Tim Knudsen (2000) har påpeget. Det vender vi tilbage til.

\section{Regimeteorier}

Den klassiske arbejdermobiliseringstilgang ser velfærdsstaten som resultat af arbejderklassens politiske kampe og dens varierende styrke; men sjældent eller aldrig har socialdemokratierne haft regulært flertal. De har derfor været henvist på koalitionspartnere eller $\mathrm{i}$ det mindste en parlamentarisk accept af socialdemokratiske mindretalsregeringer. ${ }^{6}$ Derfor rekonstruerede Esping-Andersen (1990) velfærdsstaternes historie som historien om politiske klassekoalitioner: ".. the history of political class coalitions is the most decisive cause of welfare-state variations" (Esping-Andersen 1990:1). Det betød, at interessen blev koncentreret om velfærdsstatslige regimer. I stedet for vægtlægning på 'mere eller mindre velfærdsstat' målt ved sociale udgifter som funktion af arbejderklassens styrke fokuseres der fx på "decommodificeringsindeks".

Hans forklaringsmodel bygger på "the nature of class mobilization (especially of the working class); class-political coalition structures; and the historical legacy of regime institutionalization" (Esping-Andersen 1990, 29), idet han umiddelbart efter tilføjer, at klasse-politiske koalitionsstrukturer er af langt større betydning end nogen enkeltklasses magtressourcer.

Esping-Andersens (1990) berømte opdeling i tre velfærdsregimer: socialdemokratiske, liberale og konservative betegner Manow $(2004,2008)$ - for derved at understrege typologiens normative karakter - ironisk 'de gode', 'de onde' og 'de grusomme'. EspingAndersen ser dem som resultat af en vellykket eller mislykket integration af middelklassen i en velfærdsstatsfremmende koalition.

I Skandinavien udviklede agrarpartier i koalition med Socialdemokratiet en velfærdstat "that provided benefits tailored to the tastes and expectations of the middle classes, but nonetheless retained universalism of rights (Esping-Andersen 1990, 31) det 'gode', socialdemokratiske regime

6 Selvsagt spillede de socialdemokratiske partier kun en indirekte rolle, da den tidlige sociallovgivning i 1880'erne, 1890'erne og tiårene derefter så dagens lys. Godt nok kan man allerede omkring den tidlige lovgivnings indførelse se de træk, der senere konstituerer Esping-Andersens typologi; men den bygger i vid udstrækning på den senere udvikling. 
in which the principles of universalism and de-commodification of social rights are extended also to the new middle classes ... Rather than tolerate a dualism between state and market, between working class and middle class, the social democrats pursued a welfare state that would promote an equality of the highest standards, not an equality of minimal needs as was pursued elsewhere (Esping-Andersen 1990, 27).

Omvendt lykkedes denne koalitionsmanøvre ikke i de angelsaksiske lande, der derfor bevarede en residuel velfærdsstatsmodel

precisely because the new middle classes were not wooed from the market to the state. In class terms, the consequence is dualism. The welfare state caters essentially to the working class and the poor. Private insurance and occupational fringe benefits cater to the middle classes (Esping-Andersen 1990, 31).

Det 'onde', liberale regime

minimize de-commodification effects, effectively contains the realm of social rights, and erects an order of stratification that is a blend of a relative equality of poverty among state-welfare recipients, market differentiated welfare among the majorities, and a classpolitical dualism between the two"' (Esping-Andersen 1990, 27).

Det kontinentale regime er - som det skandinaviske - "patterned by the new middle classes", men af historiske grunde med et andet resultat:

Developed by Conservative political forces, these regimes institutionalized a middle-class loyalty to the preservation of both occupationally segregated social insurance programs and, ultimately, to the political forces that brought them into being (Esping-Andersen 1990, 31-32).

Det 'grusomme', konservative regime er

predominated [by] the preservation of status differentials; rights, therefore, were attached to class and status. This corporatism was subsumed under a state edifice perfectly ready to displace the market as a provider of welfare; hence, private insurance and occupational fringe benefits play a truly marginal role. On the other hand, the state's emphasis on upholding status differences means that its redistributive impact is negligible (EspingAndersen 1990, 27). 
Disse korporative regimer er frembragt af kirken og stærkt familieorienterede, siger Esping-Andersen, idet 'subsidiaritetsprincippet'7 betyder, at staten kun intervenerer, når familiens kapacitet er udtømt. ${ }^{8}$

Det kontinentale, konservative regime er også, mener Manow, analytisk 'grusomt' (Manow 2008, 29). Det repræsenterer en 'residual-kategori', som omfatter lande med langt større forskellighed end den liberale og socialdemokratiske kategori. Fx indtager de sydeuropæiske lande en særlig profil (Ferrera 1996). Indplaceringen på landkortet er højst ejendommelig. Og det er bemærkelsesværdigt, at Esping-Andersen flere steder refererer til den katolske sociallæres betydning for den kontinentaleuropæiske model (Esping-Andersen 1990, 4. 17. 40. 53. 60-61. 112. 118), se også (Wilensky 1981; Boswell 1993; Castles 1994; von Kersbergen 1995), mens han ikke lægger vægt på de lutherske statskirker i Norden eller på religionens betydning i de lande, der har været præget af protestantiske frikirker med en vis modvilje mod velfærdsstaten (Manow 2008, 30). Logikken burde tilsige, at de lutherske statskirker og de reformerte protestantiske frikirker på tilsvarende måde blev inddraget $i$ analysen.

Philip Manows [og Kees van Kersbergens] udvidelse af typologiens forklaringsvariable ${ }^{9}$

Manow ser tesen om de tre velfærdsregimer som frugtbar, men finder den præget af uklarhed om de bagved liggende grunde (Manow 2008, 54). Han vil for det første inddrage valgsystemernes betydning for de socio- $\varnothing$ konomiske interessers politiske repræsentation for derved at finde en forklaring på, hvorfor det i nogle tilfælde - men ikke i alle - lykkes at integrere middelklassen. Forholdstalsvalg vil fremme partisystemer, der gør velfærdsstatskoalitioner mellem arbejderklasse og middelstand mulige, mens flertalsvalg typisk frembringer et to-partisystem, som ikke fremmer en sådan koalitionsindgåelse (Iversen \& Soskice 2006). Han vil for det andet tage udgangspunkt i de samfundsmæssige konfliktlinjer på tidspunktet for massedemokratiseringen og deres betydning for hvilke partier, der i forholdstalsvalgsystemer repræsenterer middelklassen.

Flertalsvalg vil typisk føre til dannelse af to-parti systemer, hvor middelklassen støtter midter-højre partiet, hvilket begrænser omfordelingen. Konfliktlinjen mellem kapital og arbejde er den dominerende, som 'absorberer' andre konflikter. Forholds-

$7 \quad$ Se note 5.

8 "Social insurance typically excludes non-working wives, and family benefits encourage motherhood. Day care, and similar family services, are conspicuously underdeveloped; the principle of 'subsidiarity' serves to emphasize that the state will only interfere when the family's capacity to service its members is exhausted".

9 Der er betydeligt 'overlap' for ikke at sige identitet mellem de tanker, der præsenteres af Philip Manow (2008), og dem, som er indeholdt i Manow og Kersbergen (2009). 
talsvalgsystemer disponerer derimod for flere partier, der repræsenterer mere end denne ene konfliktlinje.

I Nordeuropas homogene, protestantiske lande, hvor den lutherske kirke var tæt forbundet med staten, gav udviklingen af nationalstaten ikke grundlag for konflikt mellem kirke og stat og påvirkede derfor ej heller udviklingen af partisystemerne. Norden var en mono-konfessionel protestantisk region, hvis lutherske statskirker ikke så sig eksistentielt udfordret, da nationalstaten overtog ansvaret for områder, der hidtil havde været et kirkeligt ansvar. Identifikationen mellem nationalstat og statskirke var stort set total (Gustafsson 2003).

Den konfliktlinje, der slog igennem i partimønstret, drejede sig om forholdet mellem land og by, landbrug og industri, primær og sekundær sektor. På tidspunktet for massedemokratiseringen var de Nordiske lande udpræget landbrugslande, og det fremkaldte stærke landbopartier, der (senere) sammen med Socialdemokratiet fremmede velfærdsstatsudviklingen.

Konflikten mellem den gryende nationalstat og den katolske kirke blev derimod strukturbestemmende for de kontinentaleuropæiske landes partisystemer (Manow 2008, 62). I modsætning til Nordens lutherske statskirker følte den katolske kirke sig eksistentielt udfordret af liberale, nationale eliter. Det befordrede udvikling af kristendemokratiske partier, der knyttede såvel borgerlige som religiøse stemmer til sig.

Hingegen erleichterten dort, wo die lutherische Staatskirche mit nur wenig freikirklichem Dissent dominierte, in Skandinavien, der fehlende Anspruch auf kirkliche Überordnung über die weltliche Obrigkeit sowie die individualisierte Religion die frühe staatliche Verantwortungsübernahme in sozialpolitischen Dingen. Eine hiervon wiederum zu unterscheidende Konstellation repräsentiert Deutschland, wo eine dominante lutherische Staatskirche und eine starke katholische Minderheit traf, woraus sich eine Entwicklungsdynamik eigener Art ergab. Diese Dynamik gleicht jedoch der in den meisten Ländern Kontinentaleuropas insofern, als hier der Wohlfahrtsstaat der Konsolidierung und Stabilisierung politischer und konfessioneller Lager diente (Manow 2008, 35).

De frikirkelige, protestantiske lande (Schweiz, Holland, Storbritannien) forventes at være 'forsinkede' i deres velfærdsstatslige udvikling (Manow 2008, 37-44).

Med dette som afsæt ser Manow forskellen mellem de liberale, residuelle og de konservativt, generøse velfærdsregimer forklaret ved forskelle i valgsystemer, mens forskellene mellem de generøse - nordisk/socialdemokratiske og kontinental/konservative - regimer (med forholdstalsvalgsystemer) henføres til forskelle i de dominerende samfundsmæssige konfliktlinjer. I Skandinavien gik konfliktlinjerne mellem arbejde og kapital samt mellem by og land, mens de i de kontinentaleuropæiske regimer vedrører arbejde og kapital samt forholdet mellem stat og kirke. I Skandinavien fik agrarpartier derfor en central rolle, mens man på kontinentet fik kristendemokratiske partier. De nordiske velfærdsstater blev udviklet i en socialdemokratisk/agrar alliance, mens 
de på kontinentet blev båret frem af en socialdemokratisk/kristdemokratisk koalition.

\section{Religionen i velfærdsforskningen - en oversigt}

Som vi har set, har religion generelt spillet en nedtonet rolle i den internationale komparative velfærdsforskning, som med nogen ret kan betegnes som 'religionsblind' (Hammer 1999; Opielka 2008). Hårde socio-økonomiske variable, veletablerede politiske aktører og statsinteresser har i almindelighed domineret forklaringer, som bygger på kultur, bevidsthed og religion. Kulturen og religionen er oftest blevet tillagt en residuel rolle i 'den sorte kasse', der drages ind i forklaringerne, når de 'hårdere' data ikke slår til.

Der er dog også eksempler på, at religion har været en blandt mange variable (Wilensky 1981, Castles 1994), men når religionen er blevet tillagt forklaringsværdi, har det overvejende været i forhold til de syd- og kontinentaleuropæiske velfærdsmodeller og med en særlig vægtlægning på katolicismen (Esping-Andersen 1990, 112).

I de senere år har den ofte omtalte 'kulturelle vending' gjort sit indtog også i komparativ velfærdsforskning (van Oorschot, Opielka \& Pfau-Effinger 2008). I 2006 forsvarede Sigrun Kahl sin disputats The Religious Foundations of the Welfare State ved Humboldt Universitet i Berlin. To år senere publicerede Philip Manow sin bog Religion und Sozialstaat. Die konfessionellen Grundlagen europäischer Wohlfahrtsstaatsregime og sammen med Kees van Kersbergen har han netop redigeret og udgivet Religion, Class Coalitions and Welfare States, som bl.a. indeholder analyser af samspillet mellem religion og velfærdsstat i Italien, Holland, Frankrig, Schweiz, Sverige og USA. Michael Opielka har diskuteret 'religiøse værdi i velfærdsstaten', 'religiøse og civilreligiøse begrundelser bag socialpolitikken' og 'det kristne grundlag bag velfærdsstaten' (Opielka 2003a. 2003b. 2008). Der er grøde i en ny industri.

Manow og Kersbergens hovedteser (2009, 6-8. 13. 17) er

- $\quad$ at forståelse af den kontinentaleuropæiske velfærdsstat som spejling af en katolsk social doktrin er historisk inadækvat;

- at den reformerte protestantisme spillede en selvstændig (negativ) rolle som forsinkende for velfærdsstatsudviklingen i de lande, hvor den var fremherskende;

- at de lutherske statskirker omvendt spillede en positiv rolle for velfærdsstatsudviklingen, fordi de ikke følte sig 'truet' af statens overtagelse af en række sociale funktioner;

- at det for forståelsen af velfærdsstaternes forskelligartede udvikling er afgørende, hvem der udøvede Polanyis 'modbevægelse";

- at aktørerne bag 'modbevægelsen' i høj grad blev bestemt af religiøse forhold - tilstedeværelse eller fravær af konfliktlinjer mellem kirke og stat; 
Samfundsforskeren Sigrun Kahl (2005. 2006. 2008) har forsøgt at videreudvikle diskussionen, så den i højere grad kobler velfærdsstaternes udformning sammen med religionens indholdsmæssige side ("denominational social doctrines", Kahl 2005, 122) ikke med kristne partiers styrke, kirkers og/eller religiøse bevægelsers magt. Hun erkender, at det kan være vanskeligt at spore virkningerne af sådanne sociale doktriner, men de

have for centuries shaped both perspectives on poverty and the institutions of poor relief, even when they became part of state poverty policy. In this vein, loss of secular power by the church does not equal loss of spiritual power; it does not mean that the already existing institutions and the principles they embody and perpetuate are abandoned; and finally it does not mean that secular principles of welfare state provision are not now rooted in Christian postulates. Despite the immense changes the welfare state brought about, much of the national continuities in attitudes towards, and policies against, poverty can be traced back to religious roots (Kahl 2005, 122-123).

Religion er derfor, mener hun, et nøglebegreb i forståelsen af velfærdsstaternes forskelligartede udformning (regimer), fordi der i det enkelte land er korrelation mellem forkyndelsens 'sociale doktrin' og den valgte institutionelle struktur, hvilket skyldes, at 'religionen' er indfældet i kulturen:

Religion has influenced welfare state development by structuring the way actors construct what is a problem and which solutions are considered good and just, because, once "elected", these values are part of countries' institutional traditions. The repertoire of what was considered possible, just and efficient in a given historical situation comes from the past and elective affinities guide the political decision about reform. .... In short, a (but not the) reason that construals of "good" solutions to social policy problems differ is that institutional traditions are embedded in different cultures (Kahl 2006, 77).

Kahls tanke er m.a.o., at religion er en 'kulturel kraft', fordi

social doctrines are embedded into the 'deep structure' of secular institutions of poor relief and today social assistance, reflecting and reinforcing particular values and attitudes regarding poverty, work, and charity (Kahl 2008, 266).

... as Christian societies secularized, part of these religious doctrines became associated with secular institutions and value sets rather than confessional beliefs (Kahl 2008, 289).

... religion has worked its way into the welfare state via processes of institutionalization and secularization, thus shaping the historical antecedents, defining the playing grounds for actors, and producing societal values even as it ceases explicitly to be identified as religion. As a result, there is today a "hidden" religious curriculum that is deeply engrained into the secular institution of social assistance (Kahl 2008, 289). 
I Kahls analyse er sekularisering en "transformation of religious beliefs into economic and political ethics", idet nyere sekulære ideologier - liberalisme, socialisme, nationalisme - filtreres gennem disse eksisterende "beliefs". "For instance, Scandinavian social democrats can be described as a 'secularized Lutheran movement' and for the Scandinavian welfare states, "the element of historical continuity with the period before the start of the social democratic era in the 1930s is obvious" (Kahl 2006, 75 citerer hermed Stråth \& Sørensen 1997, 13. 19).

Med dette citat nærmer vi os den nordiske forskning, som også har været optaget af en sammenhæng mellem den skandinaviske velfærdsstat og lutheranismen.

Kahl henter sin reference fra Sørensen \& Stråth (1997), som netop også har 'kulturel konstruktion' som tema. Nina Witoszek (1997, 73-74) argumenterer 'metodisk' meget lig Kahl, når hun ser en dominerende, uudfordret kristen diskurs og normativ struktur tømt for sit religiøse indhold men slået over i "cultural cosmologies or meanings-worlds". Uffe Østergaard $(1997,69)$ ser - som Kahl - en sammenhæng, idet han hævder, at baggrunden for de nordiske velfærdsstater i mindre grad skyldes eksistensen af en særlig social struktur, men snarere at det er homogene lutherske lande. Hvis denne mentalitetshistoriske pointe holder vand, siger han, er konsekvensen, at de socialdemokratiske partier er et produkt af en sekulariseret lutheranisme snarere end af demokratisk socialisme. Stråth og Sørensen $(1997,13)$ tilføjer, at den nordiske organisation af religionen - lokal fleksibilitet og pragmatisme til trods - var 'statsorienteret'. "It is not particularly difficult to imagine the social democrats as a secularized Lutheran movement". I senere arbejder (2003. 2005) strammer Østergaard skruen med udsagnet:

Uanset hvad socialdemokratiske partiprogrammer og generationer af partimedlemmer har sagt, er den danske velfærdsstat snarere et resultat af sekulariseret lutheranisme i national klædebon end af demokratiseret socialisme. "Danmark for folket" som Socialdemokratiets valgprogram lød i 1934.

En sådan forbindelse mellem en luthersk kirke og en luthersk 'forkyndelse' på den ene side og velfærdsstatens opståen og udformning på den anden må, hvis den har noget på sig, være indirekte og sammenhængende med den særlige stats/folkekirke-konstruktion. En forklaring kan være, at den lokale sognepræst gennem århundreder på en og samme tid har repræsenteret Gud og kongen, prædiket Guds ord og indskærpet de kongelige dekreter (Thorkildsen 1997, 150) og dermed - sekulariseringen til trods - medvirket til at indkapsle en luthersk samfundsforståelse. Sognepræsterne virkede som budbringere mellem staten og bønderne - kongens øje og stemme i selv det mest afsides lokalsamfund. Præsten var kirkemand, statsembedsmand - og bonde, der delte skæbne med andre bønder (Knudsen 2000, 41. 43-44). Sognepræsterne prædikede ofte lydighed mod kongemagten og gjorde skattesnyderi til en synd (Bregnsbo 1991. 1992. 1997). Om præsten som velfærdsforvalter, se også Gustafsson (2000). 
Hvis velfærdsstatens to grundpiller er fuld beskæftigelse og social sikkerhed, modsvarer det de to lutherske støttepiller: det daglige arbejde i kald og stand og det almene præstedømme. Fuld beskæftigelse kan ses som en sekulariseret version af kaldet til arbejde, mens det almene præstedømme fremmer en 'lighedskultur', fordi forskellighed ville stride mod alle individers ligestilling, der følger af, at mennesket er skabt i Guds billede. Opbygningen af en velfærdsstat fordrer et vel integreret samfund, og siden Reformationen var de nordiske stater præget af kirkens integration i staten (Thorkildsen 1997: 159).

Det er et synspunkt, der delvis er sammenfaldende med Tim Knudsens forsøg på at forklare tilblivelsen af den universalistiske velfærdsstat med udgangspunkt i de institutionelle relationer mellem staten og kirken (Knudsen 2000. 2003). Hans udgangspunkt ligger i Skocpols tanker om institutionel arv og statskapacitet. Netop de nordiske lande har, argumenterer han, en særlig institutionel arv, som bærer ekstraordinær statskapacitet med sig. Tim Knudsen konstaterer, at universelle velfærdsstater typisk har protestantiske kirker og omvendt, at der er forskelle på kontinentale velfærdsstater domineret af katolicisme og kontinentale velfærdsstater, hvor katolske og protestantisk kirker lever side om side, og at der i Holland, Belgien og Schweiz gøres udstrakt brug af konsociationisme båret frem fra calvinsk side (Knudsen 2000, 39-40). ${ }^{10}$

Uanset om statsopbygningshensyn spillede en rolle for Reformationen, var dens konsekvens vækst i fyrstens rigdom og magt og - som en måske utilsigtet sidegevinst - kontrol over den eneste organisation, der kunne "nå ud i territoriets fjerneste hjørner" (Knudsen 2000, 41). Kirken blev statens værktøj. I de nordiske lande var der ingen rivalisering mellem kirke og stat, de var dele af samme helhed (Knudsen 2000, 42-43). Allerede under merkantilismens statsinterventionistiske system gav kontrollen med kirken et godt værktøj til fremme af statens mål. I Sverige viste kirken sig som egnet middel til at fremme kontakten til lokalsamfundene og skabe etnisk, sproglig og religiøs ensartethed (Knudsen 2000, 47).

Tim Knudsens sigte har været at skitsere mulige konsekvenser af det skandinaviske forhold mellem stat og kirke - kirkens bidrag til at styrke statsmagten, tilvejebringelsen af en ekstraordinær statskapacitet (Knudsen 2000, 59-60), men tilbage, skriver Knudsen, står at vurdere, om kirkens 'budskab', den skandinaviske lutherske lære, som trosretning også havde konsekvenser for opbygningen af velfærdsstaten.

10 Konsociationisme betegner et politisk system, der på trods af religiøse, etniske eller sproglige opdelinger af befolkningen alligevel fungerer. Sådanne systemer kendes især fra mindre, europæiske stater som Holland, Schweiz og Belgien. Der må da etableres koalitioner eller samarbejde mellem flere grupper. Forholdet mellem grupperne hviler på løbende forhandlinger, og grupperne har stor frihed og vetoret. Man taler undertiden om et samfund opdelt i flere søjler. Store dele af den offentlige forvaltning - især områderne kultur, undervisning, sundhed og socialpolitik - er uddelegeret til gruppernes organisationer. Knudsen diskuterer specielt den hollandske konsociationistiske 'søjlestruktur'. Om end den katolske kirke favoriserer en 'korporatistisk' samfundsorganisation, blev søjledelingen - i forlængelse af konflikten mellem stat og kirke om forholdet mellem offentlig og konfessionel uddannelse - primært båret frem fra ortodoks, calvinistisk side, men med støtte fra den katolske kirke. 
Den forskningsmæssige interesse i de nordiske lande har ikke mindst været rettet mod aktører, som på en eller anden måde har en tilknytning til kirken - 'kirkefolket'. Det kan være religiøst inspirerede nationaløkonomer (Kærgård 1997. 2005a. 2005b. 2006a. 2006b), kirkelige organisationer i bred forstand (Malmgart 2005, Rømer Christensen 1995, Markkola 2000, Lützen 1998) eller centrale teologiske tænkere og samfundsdebattører (Svenstrup 2000; Tønnesen 2000). Andre (Petersen 2006; Petersen \& Petersen 2007a. 2007b) har mere analytisk tolket 'velfærdsstaten' med udgangspunkt i teologen og filosoffen K.E. Løgstrups tanker om en etisk fordring, dvs. en human udlægning af Jesus' forkyndelse, i samspil med Løgstrups senere forsøg på at forene eksistentiel og samfundsmæssig etik. Det bliver derved en antydning af en mulig eksistens af en kristen civilreligion indkapslet i den danske politiske kultur.

Lutheranismens betydning for udviklingen af den nordiske model er også set i samspil med det klassiske Weberske argument om lutheranismens særlige arbejdsmoral eller med en særlig sekulariseret nordisk lutheranisme (Petersen 2000; Andersen \& Rosenbeck 2006; Melby m.fl. 2006). Der er generelt tale om 'forklaringer' og argumenter på et højt abstraktionsniveau. Andre har diskuteret lutheranismens betydning for nordisk politisk kultur (Stenius 1997).

\section{Diskussion}

Der knytter sig flere problemer til forståelsen af den nordiske velfærdsstat som barn af lutherske statskirker og evangelisk-luthersk tænkning.

Det første er, at det ikke altid står lysende klart, om der er tale om en effekt af kirken som institution og dens forhold til statsmagten eller, om der tænkes på den evangelisk-lutherske "konfessionelle samfundsmæssige doktrin", hvis en sådan findes, jf. nedenfor, eller om begge forhold spiller ind. Kun Tim Knudsen (2000) anlægger en eksplicit skelnen.

Det andet er uklarheder om, hvordan en mulig sammenhæng er skruet sammen. Hvordan kan kirken og dens lære virke som velfærdsstatens jordemoder - sådan helt konkret? Igen er Tim Knudsen rimelig præcis, når han betoner "den ekstraordinære statskapacitet". Man kan naturligvis også mene, at beskrivelserne af præsternes rolle giver et bidrag til forståelsen af sammenhængen, men det rejser et tredje problem.

Dette tredje problem kunne man kalde 'falsifikationsproblemet'. Hvor plausibelt argumentet om sammenhængen mellem velfærdsstaten og præsten som forkynder af Guds ord, statsembedsmand og bonde blandt bønder end lyder, må man spørge, hvordan hypotesen kan falsificeres. Når Uffe Østergaard som konklusion på en i øvrigt glimrende udredning af en række historiske sammenhænge skriver

Dette er den store historiske kontinuitet, som den nordiske velfærdsstat skal forstås i.

Socialdemokratiet er vigtigt, men mere som en fortsættelse af 1700- og 1800-tallets evangelisk-pietistiske bevægelser inden for rammerne af en formindsket og derfor etnisk 
homogen nationalstat efter 1864 end som oversættere af en international socialisme. Uanset hvad socialdemokratiske programmer og generationer af partimedlemmer selv har sagt, er den danske velfærdsstat snarere et resultat af sekulariseret lutheranisme i national klædebon end af demokratiseret socialisme (Østergaard 2005, 175).

er det hans tolkning af et forløb. En anden tolkning kunne lyde:

The most elaborate manifestation of the welfare state - the one we find in Sweden - is a product of Leftists in a rather secular state, often working in opposition to church officials. The welfare state may be unlikely to flourish except in a civilization in which values of neighbourly love and charity have been preached for generations: yet its establishment in Scandinavia is mostly the work of a generation of atheists or lukewarm believers. It is the product of a political struggle over the distribution of income and privilege, not a gift from heaven (Zetterberg 1982, 89-90).

Hvordan skal den sagesløse læser vælge mellem den Østergaardske og den Zetterbergske tolkning? Er der et falsifikationskriterium? Pointen er selvsagt, at det forhold, at de skandinaviske velfærdsstater med deres egenartede udformninger udmøntet i lande, der har haft en luthersk-protestantisk statskirke, ikke nødvendigvis gør de nordiske velfærdsstater til børn hverken af kirkerne eller af en luthersk social doktrin - i det omfang en sådan overhovedet måtte eksistere. Man kan næppe komme meget længere end til at mene, at de lutherske statskirker har været specielle og afvigende fra den katolske kirke derved, at de uden nævneværdig konflikt har givet plads til de nordiske velfærdsstaters udvikling.

Det fører os over i det fjerde problem. Det er i størsteparten af litteraturen uklart, om der er fokus på velfærdsstatens opståen eller på velfærdsstatens udvikling eller på begge, og det er vel ikke nødvendigvis det samme? Hvis man ved en velfærdsstat forstår den samfundsformation, der opstod efter den 2. verdenskrig, og som af samtidige iagttagere med positive eller negative konnotationer fik betegnelsen 'velfærdsstaten', synes det vanskeligt uden videre at knytte denne sammen med et 'longue durée' perspektiv, der dækker udviklingen fra Reformationen til slutningen af det 19. århundrede.

Vi har derfor for det femte et periodiseringsproblem. Hvis tyngden i 'forklaringen' af en nutidig samfundsform ligger på forhold i et forløb, der hverken sprogligt eller på anden vis kendte til tanken om 'velfærdsstaten', er der tale om en bagud rettet projektion, hvor man søger 'velfærdsstatens rødder'. Det er vigtigt at være bevidst om, hvad der er forskningens sigte. Det er ikke udelukket, at et fænomens opståen har en anden eller andre forklaringer end fænomenets udvikling.

For det sjette er det et spørgsmål, om der overhovedet eksisterer 'trosbetingede sociale doktriner' som led i det konfessionelle grundlag - eller som mindstemål afledt af autoritative stemmer, der ser dem som funktion af dette grundlag. 
Svaret er, hvad katolicismen angår, bekræftende, fordi der foreligger et officielt tekstkorpus, som definerer sociale principper og moralsk lære oftest udmøntet i pavelige encyklika. ${ }^{11}$ Talrige tyske socialpolitiske tekster refererer eksplicit til katolsk sociallære eller katolske sociale doktriner (fx Schoen 1998; von Nell-Breuning 1979. 1985. 1990).

Det er mere diskutabelt, om man kan tale om en evangelisk-luthersk social doktrin. Nok er det sandt, at visse synspunkter - måske endog en "protestantisk samfundsdoktrin" (Thorkildsen 1997, 144) eller en "Lutheranismens sociale doktrin" (Østergaard 2005, 160-166) - kan udledes af Luthers skrifter ${ }^{12}$ (Andersen 2006). De er skrevet i en 1500-tals kontekst og giver derfor en vis mening fx i Kahls analyser af fattiglovgivningen, men de kan næppe lægges til grund for bestemmelsen af et protestantisk syn på 'velfærdsstaten' i dagens samfund. Svend Andersen $(2009,14)$ er da også i sin analyse opmærksom på det tidsbundne i den lutherske politiske etik og fokuserer derfor på, om det er muligt at reformulere eller rekonstruere den lutherske politiske etik, så den såvel intellektuelt som politisk modsvarer dagens vilkår. ${ }^{13}$

Hertil kommer, at i hvert fald den danske folkekirke ikke som 'institution' har en holdning til samfundspolitiske spørgsmål, og at der ikke findes noget organ, som autoritativt kan forholde sig til sociale eller andre spørgsmål i tiden. Forholdene er anderledes i andre lutherske kirker, hvor der fx i USA (Evangelical Lutheran Church in America), den tyske evangeliske kirke (Evangelische Kirche in Deutschland, EKD) eller den Anglikanske kirke i England findes koordinerende og synode-lignende institutioner, som forholder sig til mere principielle spørgsmål, herunder også velfærdspolitiske emner.

Da den norske professor i socialpolitik, Steinar Stjernø skrev solidaritetens idéhistorie, fandt han ej heller nogen 'autoriseret talsmand' for lutheranismen. I sin belysning af solidaritetsbegrebet i en luthersk forståelse var han derfor henvist til en analyse af resolutioner og dokumenter fra Det lutherske Verdensforbund, da ikke andre bedre kunne siges at repræsentere, hvad man kunne kalde en luthersk social etik (Stjernø 2004, 78).

En række kirkehistoriske fremstillinger (Norman 1976; Tønnesen 2000; Grimley 2004) antyder, at kirkefolket står lige så 'delt' i synet på begrebet 'velfærdsstaten' som alle andre. Det lægger ikke ligefrem op til en 'en til en'-relation mellem en luthersk social doktrin og velfærdsstaten.

11 Rerum Novarum 1891, Quadragesimo Anno 1931, Mater et Magistra 1961, Pacem in Terris 1963, Populorum Progressio 1967, Octogesima Adveniens 1971, Laborem Exercens 1981, Sollicitudo Rei Socialis 1987, Centesimus Annus 1991, Fides et Ratio 1998, Pontifical Council for Justice and Peace 2004, Deus Caritas est 2005, Caritas in veritate 2009. Se videre http:/ / www.papalencyclicals.net/encyclical.htm.

12 Mest interesssant i sammenhængen er An den christlichen Adel deutscher Nation von des christlichen Standes Besserung (udgivet omkring 1520) og Von welttlicher Uberkeytt, wie weit man yhr gehorsam schuldig sey 1523.

13 Svend Andersen bygger sin rekonstruktion på en søgen efter en sekulær, generel politisk teori, som er komplementær til en kristen etik, der hviler på næstekærlighed. Han finder således en vis kompatibilitet mellem John Rawls retfærdighedsteori og en luthersk politisk etik. 
For at få et empirisk grundlag har vi (Petersen \& Petersen under udgivelse b) som et dansk supplement til Aud Tønnesens mere dybtgående norske analyse (Tønnesen 2000) gennemført en undersøgelse af 'det danske kirkefolks' syn på velfærdsstaten i perioden fra slutningen af 1940rne til 1965. Den viser i alle tilfælde en meget forskelligartet opfattelse, som ikke gør det sandsynligt at tale om, at der i den danske folkekirke og de til den knyttede er en udpræget enighed om synet på velfærdsstaten.

\section{Konklusion}

Vi er ret overbeviste om, at der er 'noget om snakken'; men vi er samtidig kritiske, fordi den intuitive accept af religionens betydning står over for vanskeligheder først og fremmest i henseende til falsifikationskriterium og kanaliseringsmekanisme. Der er derfor gode grunde til at videreudvikle en tilgang med afsæt i religion som forklarende variabel men på en sådan måde, at 'forklaringen' får fastere grund under fødderne.

\section{REFERENCER}

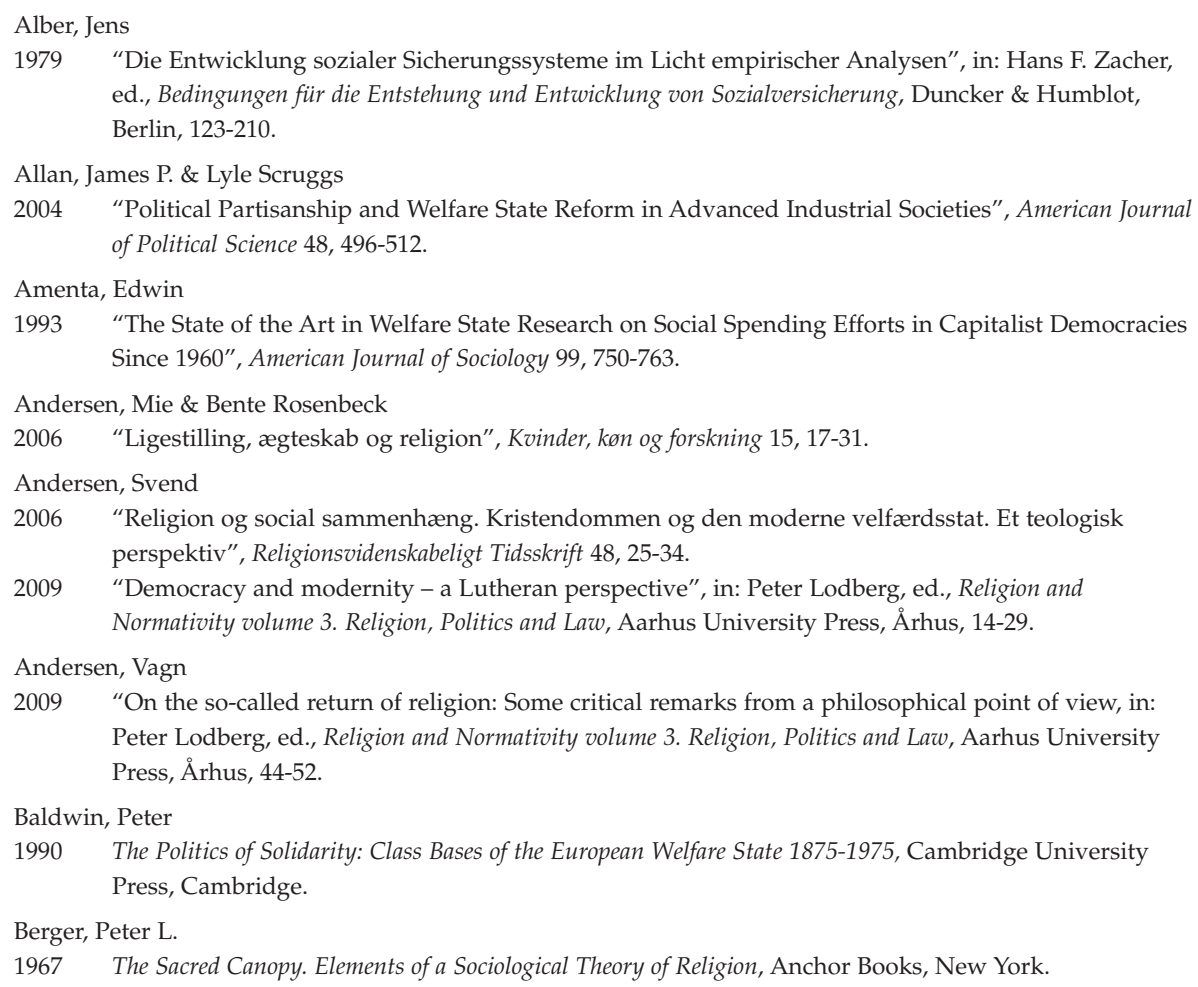


Boswell, Jonathan

1993 "Catholicism, Christian Democrats and reformed capitalism", in: Colin Crouch \& David Marquand, eds., Ethics and markets: Cooperation and competition within capitalist economies, Blackwell, Oxford, $48-65$

Bregnsbo, Michael

1991 "Clerical Attitudes towards Society in the Age of Revolution: Points of View on Government, Freedom, Equality and Human Rights in Danish Sermons", Scandinavian Journal of History 16, 1-25.

1992 Gejstlighedens syn på samfund og øvrighed 1775-1880, belyst ved trykte prædikener og taler, Den danske historiske Forening, København.

1997 Samfundsorden og statsmagt set fra prædikestolen. Udviklingen i præsternes syn på samfundsorden og statsmagt $i$ Danmark 1750-1848, Museum Tusculanums Forlag, København.

Caritas in veritate, Encyclical letter of the supreme Pontif Benedict XVI

2009 http://www.papalencyclicals.net/ (set 20.7 2009).

Carlsen, Erik Meier

2006 "Den skjulte kristendom", leder i BT, 14. april 2006.

Castles, Francis G

1982 "The impact of parties on public expenditures", in: Francis G. Castles, ed., The Impact of Parties, Sage Publications, Beverley Hills, 21-96.

1994 "On Religion and Public Policy: Does Catholicism make a difference?", European Journal of Political Research 25, 19-40.

Centesimus Annus, A message from Pope John Paul II on the 100 th anniversary of Rerum Novarum

1991 http:/ / www.vatican.va (set 1.9 2008).

Christensen, Hilda Rømer

1995 Mellem backfische og pæne piger. Køn og kultur i KFUK 1883-1940, Museum Tusculanums Forlag, København.

Deus Caritas est. Encyclical letter of Pope Benedict XVI

2005 http:/ / www.vatican.va (set 1.9 2008).

Esping-Andersen, Gøsta

1990 The Three Worlds of Welfare Capitalism, Polity Press, Oxford.

1999 Social Foundations of post-industrial Economies, Oxford University Press, Oxford.

Evans, Peter, Dietrich Reuschemeyer \& Theda Skocpol

1985 Bringing the State Back In, Cambridge University Press, Cambridge.

Ferrera, Maurizio

1996 "The 'Southern Model' of Welfare in Social Europe", Journal of European Social Policy 6, 17-37.

Fides et ratio. A message of Pope John Paul II on the relation between Faith and Reason,

1998 http:/ / www.vatican.va (set 1.9 2008)

Flora, Peter

1981 "Stein Rokkans Makro-Modell der politischen Entwicklung Europas: Ein Rekonstruktionsversuch", Kölner Zeitschrift für Soziologie und Sozialpsychologie 33, 397-436.

1983 "Introduction", in: P. Flora, ed., Growth to Limits. The Western European Welfare States since World War II. Vol. I: Sweden, Norway, Finland, Denmark, de Gruyter, New York, 11-26.

Flora, Peter \& J. Heidenheimer

1981 "Introduction", in: P. Flora \& J. Heidenheimer, eds., The Development of Welfare States in Europe and America, Transaction Publishers, New Brunswick N.J., 17-34

Flora, Peter \& Jens Alber

1981 "Modernization, democratization, and the development of welfare states in Western Europe", in: P. Flora \& J. Heidenheimer, eds., The Development of Welfare States in Europe and America, Transaction Publishers, New Brunswick N.J., 125-146. 
Flora, Peter, Stein Kuhnle \& David Urwin

1999 State Formation, Nation Building and Mass Politics in Europe: The Theory of Stein Rokkan, Oxford University Press, Oxford.

Fonsmark, H.

1999 Historien om den danske utopi, Gyldendal, København.

Grimley, M.

2004 Citizenship, Community and the Church of England. Liberal Anglican Theories of the State between the Wars, Oxford University Press, Oxford.

Gustafsson, Göran

2003 "Church-State Separation Swedish Style", West European Politics 26, 51-72.

Gustafsson, Harald

2000 "Præsten som velfærdsforvalter i tidligt moderne tid", in: Tim Knudsen, ed., Den nordiske protestantisme og velfxrdsstaten, Aarhus Universitetsforlag, Århus, 87-97.

Hammer, Inger

1999 Emancipation och religion. Den svenska kvinnerörelsens pionjärer i debatt om kvinnans kallelse ca 18601900, Carlssons, Stockholm.

Heclo, Hugh

1974 Modern Social Politics in Britain and Sweden, Yale University Press, New Haven.

Heidenheimer, A.J.

1983 "Secularization Patterns and the Westward Spread of the Welfare State, 1883-1983. Two dialogues about how and why Britain, the Netherlands, and the United States have Differed", Comparative Social Research 6, 3-65.

Hicks, Alexander \& Joya Misra

1993 "Political Resources and the Growth of Welfare in Affluent Capitalist Democracies", American Journal of Sociology 99, 668-710.

Huber, Evelyne, Charles Ragin \& John D. Stephens

1993 "Christian Democracy, Constitutional Structure, and the Welfare State", American Journal of Sociology 99, 711-749.

Huber, Evelyne \& John D. Stephens

2001a Development and Crisis of the Welfare State. Parties and Policies in Global Markets, University of Chicago Press, Chicago.

2001b "Welfare state and production regimes in the era of retrenchment", in: Paul Pierson, ed., The New Politics of the Welfare State, Oxford University Press, New York, 107-145.

Iversen, Torben \& David Soskice

2006 "Electoral institutions and the politics of coalitions: Why some democracies redistribute more than others", American Political Science Review 100, 165-181.

Kahl, Sigrun

2005 "The Religious Roots of Modern Poverty Policy, Catholic, Lutheran and Reformed Protestant Traditions Compared," European Journal of Sociology 46, 91-126.

2006 The Religious Foundations of the Welfare State: Poverty Regimes, Unemployment, and Welfare-to-Work in Europe and the United States. Dissertation zur Erlangung des akademischen Grades doctor philosophiae eingericht an der Philosophischen Fakultät III der Humboldt-Universität zu Berlin, Berlin.

2009 "Religious social doctrines and poor relief: a different causal pathway", in: Philip Manow \& Kees van Kersbergen, eds., Religion, Class Coalitions and Welfare States, Cambridge University Press, Cambridge, 266-294.

Kalyvas, Stathis N.

1996 The Rise of Christian Democracy in Europe, Cornell University Press, Ithaca. 
Kersbergen, Kees van

1995 Social Capitalism. A study of Christian Democracy and the Welfare State, Routledge, London.

Knudsen, Tim

2000 "Tilblivelsen af den universalistiske velfærdsstat" in: Tim Knudsen, ed., Den nordiske protestantisme og velfærdsstaten, Aarhus Universitetsforlag, Århus, 20-64.

2003 “De nordiske statskirker og velfærdsstaten", in: Klaus Petersen, ed., 13 historier om den danske velfærdsstat, Odense Universitetsforlag, Odense, 37-47.

Korpi, Walter

1983 The Democratic Class Struggle, Routledge Kegan \& Paul, London.

2006 "Power Resources and Employer-Centered Approaches in Explanations of Welfare States and Varieties of Capitalism. Protagonists, Consenters, and Antagonists", World Politics 58, 167-206.

Kærgård, Niels

1997 "Tre økonomiske professorers teologi", Kirkehistoriske Samlinger VII.8.C, 129-197.

2005a "Den lille kristne nationalstat: historie og dilemmaer", in: J.H. Schjørring \& J.T. Bak, eds., Velfxrdsstat og kirke, Anis, København, 35-51.

2005b "Teologerne og økonomien", i Samfundsøkonomen 3, 26-28.

2006a "Det tidehvervske i dansk politik: Liberalt Centrum og Dansk Folkeparti", in: J.H. Schjørring \& J.T. Bak, eds., Udfordringer til Folkekirken: kirken - staten - folket, Anis, København, 169-220.

2006b The Founding Fathers of the Welfare State: Mathematical Economists and Christian believers. Unpublished conference paper. Københavns Universitet.

Laborem Exercens. A message of Pope John Paul II on the $19^{\text {th }}$ anniversary of Rerum Novarum

1981 http://vatican.va (set 1.9 2008).

Lindhardt, Jan

2005 Folkekirke? Kirken i det danske samfund, Hovedland, Højbjerg.

Lützen, Karin

2003 "Den borgerlige filantropi som forudsætning for velfærdsstaten", in: Klaus Petersen, ed., 13 historier om den danske velfærdsstat, Odense Universitetsforlag, Odense, 47-58.

Malmgart, Liselotte

2005 “To reaktioner på den danske socialreform i 1933" in: J.H. Schjørring og J.T. Bak (eds.), Velfærdsstat og Kirke, Anis, København, 53-68

Manow, Philip

2004 "The Good, the Bad and the Ugly: Esping-Andersen's regime typology and the religious roots of the western welfare state", Working Paper 04/3, Max-Planck Institute for the Study of Societies. http://mpifg.de/pu/workpap/wp04-3/wp04-3.html (set 1.9 2008).

2008 Religion und Sozialstaat. Die konfessionellen Grundlagen europäischer Wohlfahrtsstaatsregime, Campus Verlag, Frankfurt/New York.

Manow, Philip \& Kees van Kersbergen

2006 "The Impact of class coalitions, cleavage structures and church-state conflicts on welfare state development", Working Papers Political Science No. 2006/03, Department of Political Science, Vrije Universiteit, Amsterdam.

2009a Religion, Class Coalitions and Welfare States, Cambridge University Press, Cambridge.

2009b "Religion and the Western Welfare State. The theoretical context", in: Philip Manow \& Kees van Kersbergen, eds., Religion, Class Coalitions and Welfare States, Cambridge University Press, Cambridge,1-38.

Mater et Magistra. Encyclical of Pope John XXIII on Christianity and Social Progress

1961 http:/ / www.vatican.va (set 1.9 2008).

Markkola, Pirjo

2000 Gender and Vocation. Women, Religion and Social Change in the Nordic Countries, 1830-1940, Finnish Literature Society, Helsinki. 
Marshall, T. H.

1950 Citizenship and social class and other essays, Cambridge University Press, Cambridge.

McGuire, Brian Patrick

2008 Da himmelen kom nærmere. Fortællinger om Danmarks kristning 700-1300, Alfa, København.

Melby, Kari, Anu Pylkkänen, Bente Rosenbeck \& Christina Carlsson Wetterberg

2006 Inte ett ord om kärlek, Äktenskap och politik i Norden ca. 1850-1930, Makadam Förlag/Museum Tusculanums Forlag, Lund.

Morgan, K.J.

2002 "Forging the Frontiers between State, Church, and Family: Religious Cleavages and the Origins of Early Childhood Education and Care Policies in France, Sweden and Germany", Politics \& Society, 113-148.

Möhle, Marion

2001 Vom Wert der Wohlfahrt. Normative Grundlagen des deutschen Sozialstaates, Westerwald Verlag Ingrid Görlitz, Wiesbaden.

Nell-Breuning, Oswald von

1979 Soziale Sicherheit? Zu Grundlagen der Sozialordnung aus christlicher Verantwortung, Herder Verlag, Freiburg.

1985 Gerechtigkeit und Freiheit. Grundzüge katholischer Soziallehre, G. Olzog, München.

1990 Baugesetze der Gesellschaft. Solidarität und Subsidiarität, Herder Verlag, Freiburg.

Norman, E.R.

1976 Church and Society in England 1770-1970, A Historical Study, Oxford University Press, Oxford.

Norris, Pippa \& Ronald Inglehart

2004 Sacred and Secular. Religion and Politics Worldwide, Cambridge University Press, New York.

Octogesima Adveniens. Apostolic letter of Pope Paul VI

1971 http:/ / www.vatican.va (set 1.9 2008).

Oorschot, Wim van, Michael Opielka \& Birgit Pfau-Effinger

2008 Culture and Welfare State. Values and Social Policy in Comparative Perspective, Edward Elgar, Cheltenham.

Opielka, Michael

2003a "Religiöse Werte im Wohlfahrtsstaat", in: Jutta Almindinger, ed., Entstaatlichung und soziale Sicherheit. Verhandlungen des 31. Kongresses der Deutschen Gesellschaft für Soziologie in Leipzig 2002, Leske + Budrich, Opladen (CD-Rom).

2003b “Religiöse und zivilreligiöse Begründungen sozialpolitischer Strategien", in: Manfred Brocker, Hartmut Behr \& Mathias Hildebrandt, eds., Religion - Staat - Politik. Zur Rolle der Religion in der nationalen und internationalen Politik, Westdeutscher Verlag, Wiesbaden, 167-185.

2008 "Christian Foundations of the welfare state: Strong cultural values in comparative perspectives", in: Win van Oorschot, M. Opielka \& B. Pfau-Effinger, eds., Culture and Welfare State. Values and Social Policy in Comparative Perspective, Edward Elgar, Cheltenham, 89-114.

Orloff, Ann S.

1988 "The Political Origins of America's Belated Welfare State”, in: M. Weir, A.S. Orloff \& T. Skocpol, eds., The Politics of Social Policy in the United States, Princeton University Press, Princeton N.J., 37-80.

Orloff, Ann S. \& Theda Skocpol

1984 "Why not equal protection? Explaining the politics of public social spending in Britain 1900-1911, and the United States, 1880s-1920", American Sociological Review 49, 726-750.

Pacem in Terris. Encyclical of Pope John XXIII on establishing universal peace in truth, justice, charity, and liberty 1963 http:/ / www.vatican.va (set 1.9 2008). 


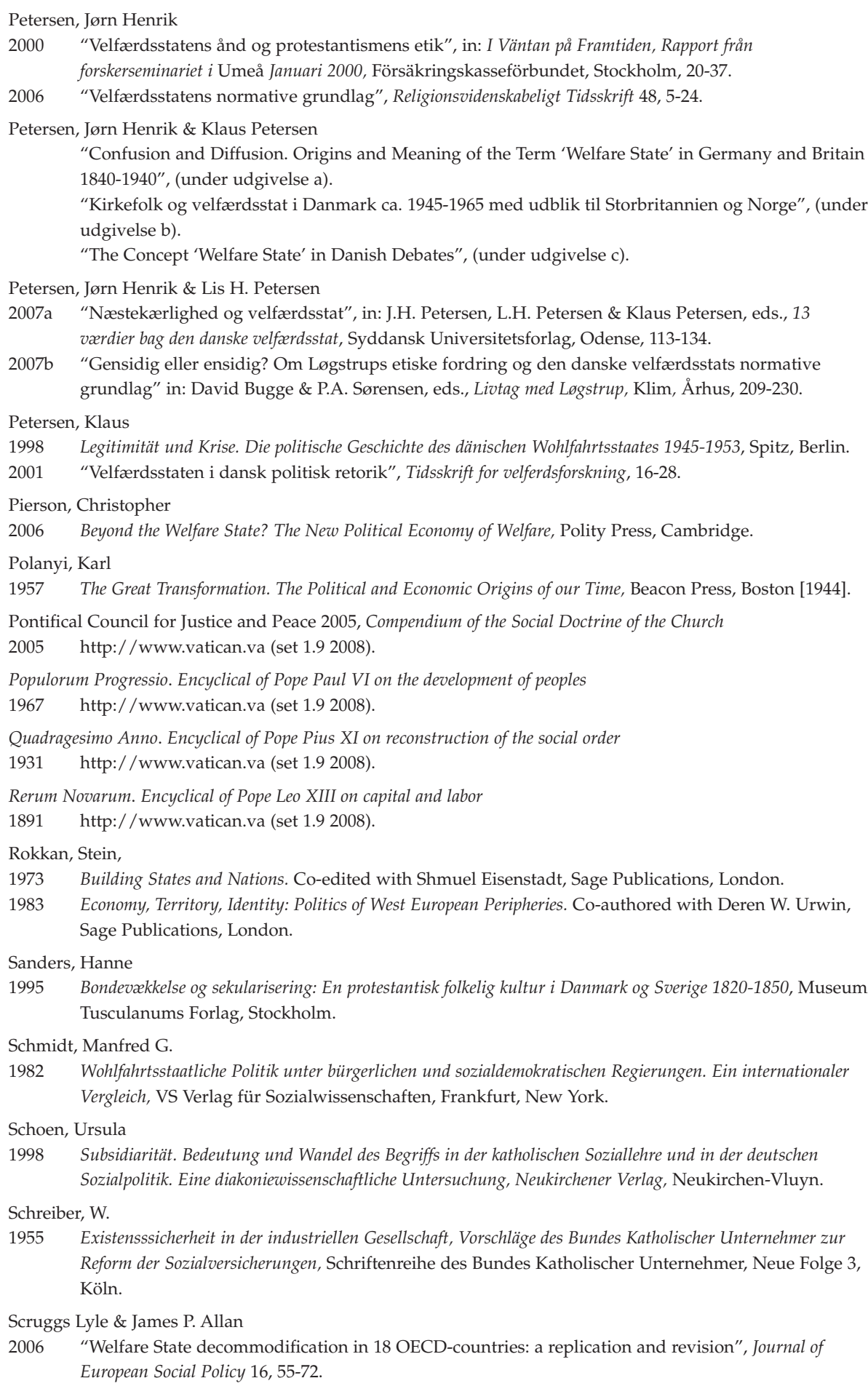


Skocpol, Theda

1985 "Bringing the state back in. Strategies of analysis in current research", in: Evans, Peter, Dietrich Reuschemeyer \& Theda Skocpol, eds., Bringing the State Back In, Cambridge University Press, New York, 3-43.

Skocpol, Theda \& Kenneth Finegold

1982 "State Capacity and Economic Intervention in the Early New Deal", Political Science Quarterly 97, 255-278.

Skocpol, Theda \& Edwin Amenta

1986 "States and Social Policies", Annual Review of Sociology 12, 131-157.

Sollicitudo Rei Socialis. A message from Pope John Paul II on the $20^{\text {th }}$ anniversary of Populorum Progressio

1987 http:/ / www.vatican.va (set 1.9 2008).

Stephens, John D.

1979 The Transition from Capitalism to Socialism, Macmillan, London.

Stenius, Henrik

1997 "The Good Life is a Life of Conformity" in: Øystein Sørensen \& Bo Stråth, eds., The Cultural Construction of Norden, Scandinavian University Press, Oslo, Oxford, 161-171.

Stjernø, Steinar

2004 Solidarity in Europe. The History of an Idea, Cambridge University Press, Cambridge.

Stråth, Bo \& Ø. Sørensen

1997 "Introduction. The Cultural Construction of Norden" in: Øystein Sørensen and Bo Stråth, eds., The Cultural Construction of Norden, Scandinavian University Press, Oslo, Oxford, 1-24.

Svenstrup, T.

2000 “Den etiske socialisme. Biskop Martensens samfundssyn i 1870erne" in: Tim Knudsen, ed., Den nordiske protestantisme og velfærdsstaten, Aarhus Universitetsforlag, Århus, 98-123.

Thorkildsen, Dag

1997 "Religious Identity and Nordic Identity", in: Øystein Sørensen \& Bo Stråth, eds. The Cultural Construction of Norden, Scandinavian University Press, Oslo, Oxford, 138-160.

Tønnesen, Aud V.

2000 ".... et trygt og godt hjem for alle"? Kirkelederes kritikk av velferdsstaten etter 1945, Stiftelsen kirkeforskning, Trondheim.

Weir, Margaret \& Theda Skocpol

1985 "State structures and the possibilities for "Keynesian" responses to the great depression in Sweden, Britain and the United States", in: Peter Evans, Dietrich Reuschemeyer \& Theda Skocpol, eds., Bringing the State Back In, Cambridge University Press, New York, 107-163.

Wilensky, Harold L.

1975 The Welfare State and Equality: Structural and Ideological Roots of Public Expenditure, University of California Press, Berkeley.

1976 The "New Corporatism". Centralization and the Welfare State, Sage Publications, London.

1981 "Leftism, Catholicism, and Democratic Corporatism: The Role of Political Parties in Recent Welfare State Development" in: Peter Flora \& A. J. Heidenheimer, eds., The Development of Welfare States in Europe and America, Transaction Books,New Brunswick, 345-382.

Witoszek, Nina

1997 "Fugitives from Utopia: The Scandinavian Enlightenment Reconsidered", in: Øystein Sørensen \& Bo Stråth, eds., The Cultural Construction of Norden, Scandinavian University Press, Oslo, Oxford, 72-90.

Zetterberg, Hans L.

1984 "The Rational Humanitarians", Daedalus, 113, 75-92. 
Østergaard, Uffe

1997 "The Geopolitics of Nordic Identity - From composite States to Nation States", in: Øystein Sørensen and Bo Stråth, eds., The Cultural Construction of Norden, Scandinavian University Press, Oslo, Oxford, 25-71.

2003 "Lutheranismen, danskheden og velfærdsstaten" in: Klaus Petersen, ed., 13 historier om den danske velfxrdsstat, Odense Universitetsforlag, Odense, 27-36.

2005 "Lutheranismen og den universelle velfærdsstat" in: J.H. Schjørring og J.T. Bak, eds., Velfærdsstat og kirke, Anis, København, 147-84.

Jørn Henrik Petersen, professor, dr.phil. et lic.oecon. Klaus Petersen, professor, ph.d.

Institut for Statskundskab, Syddansk Universitet 